\title{
A Systematic Review of the Environmental Impacts of GM Crop Cultivation as Reported from 2006 to 2011
}

\author{
Oliver Knox ${ }^{1}$, Clare Hall ${ }^{1}$, Alistair McVittie ${ }^{1}$, Robin Walker ${ }^{2}$, Bruce Knight ${ }^{3}$ \\ ${ }^{1}$ Scotland's Rural College, Edinburgh, UK; ${ }^{2}$ Scotland's Rural College, Aberdeen, UK; ${ }^{3}$ Innovation Management, Cambridgeshire, \\ UK. \\ Email: oliver.knox@sruc.ac.uk
}

Received February $21^{\text {st }}, 2013$; revised March $26^{\text {th }}, 2013$; accepted April $7^{\text {th }}, 2013$

Copyright (C) 2013 Oliver Knox et al. This is an open access article distributed under the Creative Commons Attribution License, which permits unrestricted use, distribution, and reproduction in any medium, provided the original work is properly cited.

\begin{abstract}
The current generation of genetically modified crops have shown potential to enhance agricultural productivity and alter farm production economics, but there remains global divergence in adoption of the technology due in part to uncertainty in the underlying science. In an attempt to address this, a systematic review was undertaken, which asked the question "What are the environmental impacts of the global cultivation of GM crops?" A database search statement generated over 19000 hits, which distilled down to 28 articles from which data was recovered to generate a set of R values, where $\mathrm{R}$ was the ratio of the GM divided by the conventional field data. Meta-analysis of this data indicated that under GM $\mathrm{R}$ had significantly increased from a background level of 1 to a mean value of 1.31. This increase in $R$, although positive, is not indicative of an environmental benefit due to the difficulty in assigning either benefits or disadvantages to the many indicators that were encompassed within the review. Subsequent regression analysis indicated that there was no standard model to explain the observed variation in $\mathrm{R}$ values. However, in models for both cotton and maize, variables relating to the design of the study had a significant effect, but these variables were not related to trait or gene insertion and were generally either year, country or change in cultivation practice in origin. Narrative analysis of the authors published interpretations indicated GM had no adverse effects in $85 \%$ of papers, $10 \%$ reported a beneficial effect and only 5\% a deleterious impact. The conclusion of this study is that GM adoption has had an impact on its environment, but that the underlying cause of this impact is not due to the genetic modification and the effect on the environment is generally seen as not being adverse.
\end{abstract}

Keywords: GM; Systematic Review; Meta-Analysis; Environmental Indicators

\section{Introduction}

In the years since the introduction of commercial genetically modified (GM) crops in 1996, there has been an accumulated planting of over 1 billion hectares currently across 29 countries growing 12 commercial GM crops that express herbicide tolerance, insect resistance, anti viral or combinations of these traits [1]. The corresponding level of farmer uptake makes GM cropping the fastest crop technology adoption in the history of modern agriculture with the global cultivated area continuing to increase by as much as $10 \%$ year on year [1]. In the face of this continued increase in adoption there remains continued debate regarding the environmental consequences of introducing GM crops and this underlies much of the observed global disparity in the uptake of the technology. Much of the governmental and public uncertainty in the environmental safety of the GM technology arises out of divergence in personal belief and levels of trust in both companies that hold the rights to the technology and the scientific institutes that have conducted the risk assessments [2]. With regard to the scientific risk assessments and associated experimentation there are many criticisms, particularly from Non Government Organisations, that these have often been insufficient. According to several research groups, many experiments used to test the environmental safety of GM crops are not field relevant, lack replication in design, cover single or limited timescales, are limited in what they record or have been incomplete due to their destruction by members of society opposed to the cultivation of GM [2-4]. Despite the potential flaws in some of the experiments conducted there is an abundance of literature 
covering a range of crops, traits, countries and environmental impact data [5].

The introduction of GM crops has allowed growers to alter management practices, most noticeably through the use of less or alternative pesticide sprays [6,7]. Benefits to the environment have been associated with this change in pesticide application $[6,8,9]$, but these studies do not often extend to the wider environment. In addition to this there remain issues with the release of the GM that are currently unanswered. These issues predominantly lay in the impacts that GM adoption may have on both the crop and wider environment, whether deleterious or beneficial.

Traditionally the interpretation of existing scientific data is undertaken by single authors or small scientific groups conducting reviews of the published literature relevant to a particular subject area as part of a new or existing project. Similar exercises have been undertaken for GM crops and their associated technology often presenting very clear and concise interpretation of the major findings [7,10-14]. However, the review process does little to address the discrepancies in personal concerns over GM or provide systematic evaluation of the covered literature, methodologies and measurement tools. In order to address this, an approach is required that improves transparency, reproducibility, objectivity and provides confidence in the outcomes [15]. One such approach to attempt to mitigate these issues is through systematic review [16]. In light of this, a review of the available literature where field evaluation of commercial GM and conventional crops was compared was systematically gathered, analysed and reported.

\section{Methods}

\subsection{Primary Objective}

The primary objective was to answer the question: "What have been the environmental impacts of the global cultivation of GM crops?"

Execution of a systematic review requires that a specific question be posed containing four key elements [17]. The question for this review contained the following components: 1) Subject Population: an environmental indicator (e.g. a population change in arthropod, microbiological, earthworm or weed species) recorded at the field level or above; 2) Exposure: the cultivation of any commercial GM modification in the last 5 years (i.e. 2006 onwards)-subsequently modified to any publication in the last 5 years; 3) Comparator: seasonal or environmental impacts where there was comparison with a conventional (non-GM) cropping system; and 4) Outcome: Long term and seasonal environmental impacts, reported as changes in the abundance, density, biomass, number, and measure of function of the populations of arthropod, microbiological, earthworm or weed species as a result of the intervention.

\subsection{Search Strategy}

In order to address the posed question a web based search strategy was established from keywords that were agreed by the panel conducting the review with the funders, based on the components of the question that had been identified (Table 1). The statement was further refined with numerous scoping studies and a peer reviewed protocol. The use of the wildcards $*$ and $\$$ as well as SAME or quotation marks, as keyword linkers, had to be altered for syntax preferences of some search engines. Keywords were linked with the OR command and search statements linked with AND.

\subsection{Databases and Search Engines}

Alternative methods for searching some databases (e.g. using "advanced" instead of "expert" search entry options) resulted in some truncation of the search term and, in some databases, the order of the search sets linked by the AND command made a difference to the outcome of the Boolean search. These changes were noted when the search was run and the results recorded. Search engines were considered and subsequently not used as they produced over 2 million hits to several variations of the search terminology. Attempting truncated versions of the search strategy in the search engines also failed to reduce the number of hits to a manageable level and as such the decision was taken to exclude them.

The following databases were searched: Web of Knowledge, Science Direct, CAB Direct and COPAC.

\subsection{Additional Sources of Information}

The words present in the search strategy were also used

Table 1. Components of the primary question and the descriptions of them that were used to populate a table of keywords subsequently integrated into the search statements used in the review.

\begin{tabular}{llll}
\hline \multicolumn{1}{c}{ Subject } & \multicolumn{1}{c}{ Exposure } & \multicolumn{1}{c}{ Outcomes } \\
\hline & Genetically Modified (GM) & & \multicolumn{1}{c}{ Conventional (non-GM) cropping } \\
Environmental impacts as & crop cultivation in the past 5 & Long term environmental & system. Any study comparing before \\
recorded at the scale of the & years. Any commercial genetic & impacts. Seasonal & or after GM crop cultivation OR \\
field level and above. & modification (GM trait). & environmental impacts. & comparing changes during GM crop \\
& Any GM crop. & & cultivation with a conventional crop. \\
\hline
\end{tabular}


in a manual search of the listings for publications from BCPC and Agbioview from January 2006.

The review team also contacted 14 individuals known to be working in the area of field GM trials with a view to establishing if they had knowledge of articles or grey literature potentially pertinent to this review.

\subsection{Study Inclusion Criteria}

Criteria for including studies were based on: 1) Relevant subjects including any study conducted in any country considering the environment at the field level or above, including field trials, where there was cropping of a commercial GM trait; 2) The exposure criteria were studies in which GM crop cultivation had occurred; and 3) Comparators of either the situation prior to cultivation of GM crop with the situation post GM crop cultivation or changes within the season/s when GM and conventional (nonGM) crops were cultivated together were presented.

Reported field trials could include environmental impact at a range of scales (e.g. plot, field, farm, valley, regional, countries, continental and global) across cropping types (e.g. plant species) and GM traits. The outcomes of these studies would be changes in environmental parameters (e.g. changes in species presence, changes in soil diversity and function, impact on landscape) since cultivation of a GM crop.

The review was limited to studies published since January 2006 in an attempt to build upon existing UK governmental studies and to capture the most recent work on field impacts of GM cultivation. Studies of non-commercial GM traits, and/or the use of only laboratory, glasshouse or modelled data were excluded. Further exclusion of articles that presented data acquired under experimental conditions that lacked sufficient detail to be reproducible was conducted during full paper review.

\subsection{Title Review, Abstract Screening and Full Review}

Of the identified 19,499 hits made from the database searches, limitations to extraction meant that only 4459 titles were extracted. The titles were screened against inclusion criteria by members of the review team, who undertook a Kappa analysis on review outcomes of a sub-set of the extracted titles to ensure consistency. An additional 12 papers were offered by contacted experts during the title review process. Having reduced the number of titles, the abstracts were screened against inclusion criteria, again with Kappa analysis. The bibliographies of papers that passed the abstract review were screened for suitable titles and after abstract screening added an additional 21 papers for full review. 102 papers passed abstract screening against the inclusion criteria for subsequent full review.
Full review of all 102 articles was conducted by two members of the review team to determine whether they contained potentially relevant comparators and data under experimental conditions that met the outlined inclusion and exclusion criteria. The final list of articles for inclusion based on comparator existence was 43 articles, which included 5 articles from bibliographies and not identified in the web searches and none of the articles contributed by the contacted experts. However, only 28 of the 102 articles contained data suitable for subsequent extraction and analysis (Figure 1). The larger body of 43 articles was subsequently used in a narrative analysis, while a more detailed meta-analysis was conducted based on the data extracted from the sub set of 28 articles.

\subsection{Study Quality Assessment}

The scientific quality of the identified 43 articles was ranked by the review authors who considered the content of the articles in accordance with CEE guidelines [17]. This was achieved by assessment of the articles for: 1) Robustness and suitability of the methods of environmental parameter assessment used; 2) trial design; 3) level of analysis (plot size, replication and number of years of trials); 4) existence of comparable intervention between treatments with a clear commercial GM and conventional component identified, 5) inclusion of baseline methods of analysis to establish the background against which the outcome is being measured; 6) level of detail of site descriptions; and 7) the apparent quality and quantity of potential data within the paper with regard to season or seasonal measurements and the number of different assessments reported.

On the basis of these criteria the reviewers assigned scores between 1 and 4 to represent: 1) valueless; 2) poor; 3) good; and 4) high quality. This screening provided a check on manuscript suitability and allowed for an initial

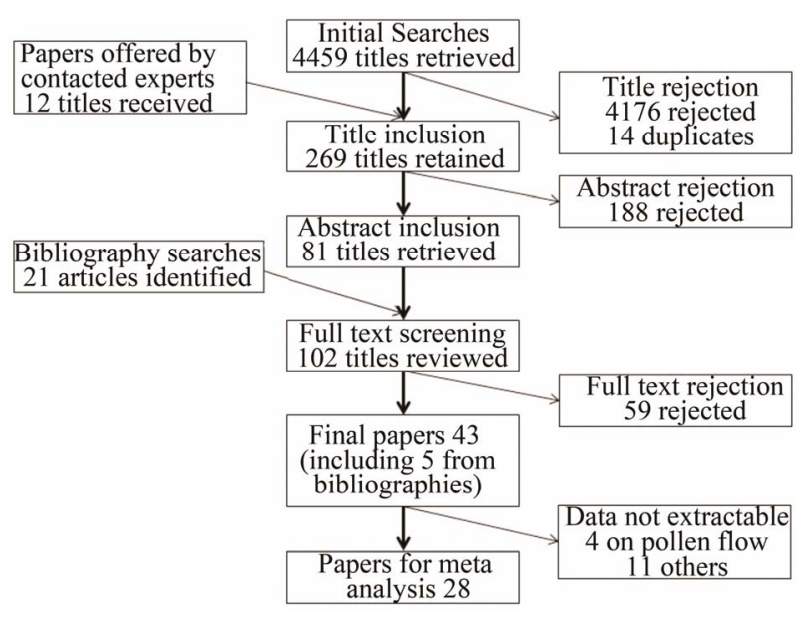

Figure 1. Flowchart illustrating the processes and sequential reduction at the various stages of the review to identify the articles and books that contributed to the systematic review. 
narrative and qualitative analysis to be undertaken.

\subsection{Data Extraction}

Environmental data for a range of functional, diversity and abundance measures pertaining to changes due to GM cultivation was extracted. Articles were initially pooled into whether they dealt with environmental impacts on microbiology (13 articles), non-target arthropods (22), earthworms (4), weeds (4) and pollen flow (4). Some articles contained information on several environmental comparators, which resulted in 47 environmental indicator studies being identified from the 43 articles. The articles were then screened for relevant and comparable sub-sets of data and comparator information based on: conventional (non-GM) cropping system, a study comparing before or after GM crop cultivation or comparing changes during GM crop cultivation with a conventional crop identified. The overall findings of the articles were recorded according to whether the authors reported deleterious, no adverse or beneficial impacts of GM cultivation. In four articles the authors had not indicated the nature of the outcome of the experimentation, consultation followed by agreement on the status of the findings was made by the review authors based on their interpretation of the articles and included in the narrative analysis.

Data extraction was taken directly from text, tables and figures within the reported work where it pertained to measures of environmental indicators that had similar comparators within the extracted article. Not all articles that passed the title, abstract and full review contained data that was suitable for extraction and analysis because either: 1) the data had no obvious GM to non-GM comparators; 2) was graphed in such a way that values could not be accurately obtained; or 3) was simply absent from either text, figures or tables within the manuscripts. Due to the decision to utilise a ratio approach for analysis, data also had to have an identified paired comparator and thus data with zero values within a possible pair was excluded. Within the arthropod data, only that which pertained to non-target organisms (i.e. Lepidoptera data was excluded as commercial Cry proteins target Lepidoptera making them target organisms whether they are pests or not) was extracted so that only unintended environmental perturbations were included. Where articles reported data from the same series of field experiments the data was pooled under the pertinent study to reduce bias from author publication prowess.

Data was extracted into Microsoft Excel where the study characteristics from the eligible articles were: author, title, year of publication, country of study, crop, trait, inserted genes, plot size, number of plots, seasonality of data, management characteristics, management modifications, environmental indicator and indicator specifics.

Four articles covered experimentation on seed move- ment or pollen flow and were segregated at this point as they did not contain GM to non-GM comparisons, but the data was of relevance to environmental or landscape level assessment of GM. Due to this the papers relating to pollen flow were extracted and analysed separately.

Reviewing the data for extraction quickly indicated that few of the articles contained sufficient detail or uniformity of information to undertake Hedge's $d$ weighted mean effect analysis, as has been recently utilised elsewhere in GM meta-analyses $[3,18]$. $\mathrm{R}$, the ratio of the geometric mean of the GM treatment divided by either the non-GM or the non-GM and modifier treatment (i.e. altered pesticide, tillage or rotation) was the adopted method for statistical analysis. The difference between these two factor identifiers resulted in 125 and 84 lines of coded data for each factor within the compiled database, respectively.

The basic premise was to determine if there was an environmental change under GM, which would be indicated by an $\mathrm{R}$ value significantly different to 1 being returned. A value of 1 would indicate no difference in effect between comparators. A value significantly different from 1 would indicate a change in the environmental indicator being assessed.

For each line of coded data entered into the database the calculated $\mathrm{R}$ value, the standard deviation, the standard error of the mean and the number of data pairs that were used to establish $\mathrm{R}$ were recorded.

\subsection{Study Quality Assessment}

The scientific quality of the identified 43 articles was ranked by the review authors who considered the content of the articles in accordance with CEE guidelines [17]. This was achieved by assessment of the articles for: 1) Robustness and suitability of the methods of environmental parameter assessment used; 2) trial design; 3) level of analysis (plot size, replication and number of years of trials); 4) existence of comparable intervention between treatments with a clear commercial GM and conventional component identified; 5) inclusion of baseline methods of analysis to establish the background against which the outcome is being measured; 6) level of detail of site descriptions; and 7) the apparent quality and quantity of potential data within the paper with regard to season or seasonal measurements and the number of different assessments reported.

On the basis of these criteria the reviewers assigned scores between 1 and 4 to represent: 1) valueless; 2) poor; 3) good; and 4) high quality. This screening provided a check on manuscript suitability and allowed for an initial narrative and qualitative analysis to be undertaken.

\subsection{Data Syntehsis and Analysis}

Initial assessment of the $\mathrm{R}$ values was conducted with Chi 
square and $\mathrm{T}$ test with the assumption that if GM adoption had no impact on the environmental indicator then the expected values would be 1 . The data was then grouped by various comparators to generate forest diagrams [19] (Figures 2-6) and the independent data within these sets analysed with unbalanced ANOVA of natural logarithm transformed data. The meta-data set analysis of environmental outcomes from GM cultivation was conducted with ordinary least squares (OLS) models, estimated (using SPSS19.0) to determine the effects of the variables collected for the meta-analysis on the observed variation in environmental outcomes as represented by the $\mathrm{R}$ values.

The purpose of this analysis was to identify whether the variation in outcome can be explained by variables related to GM traits (e.g. trait type, genes); modifiers in the conventional comparator (e.g. no modifier, tillage,

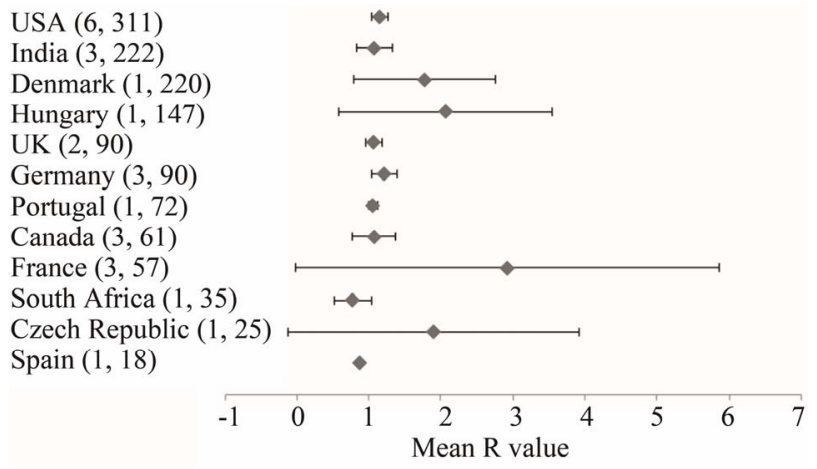

Figure 2. Forest plot of the mean $\mathbf{R}$ values by country resulting from the division of GM environmental indicator measurements by conventional paired data. Error bars represent $\mathbf{9 5 \%}$ confidence intervals derived from the meta-data set generated for this study. Numbers in brackets represent the corresponding number of studies and the number of paired data sets that went into the calculated value.

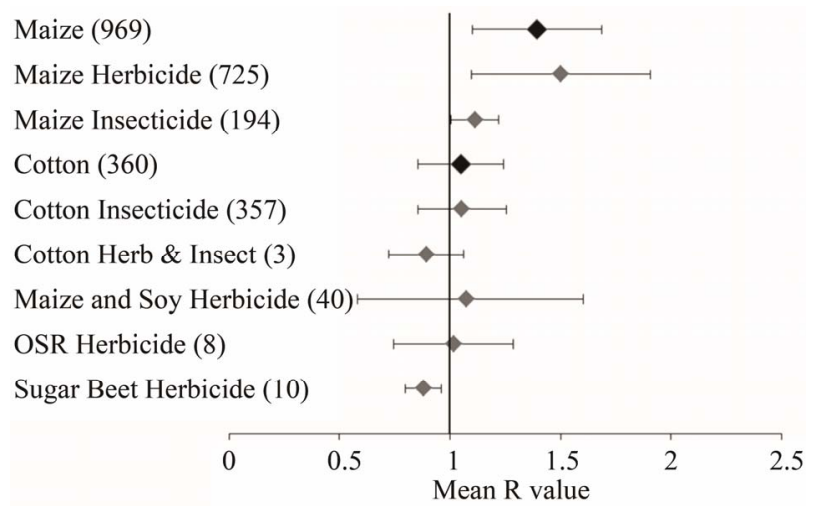

Figure 3. Forest plot of the mean $R$ value for the crops and expressed GM trait represented in the meta-data. Error bars represent $95 \%$ confidence intervals. Numbers in brackets are the paired data points used to generate the values. The values for overall maize and cotton (larger black diamonds) are presented, but are not independent of the subsequent crop data.

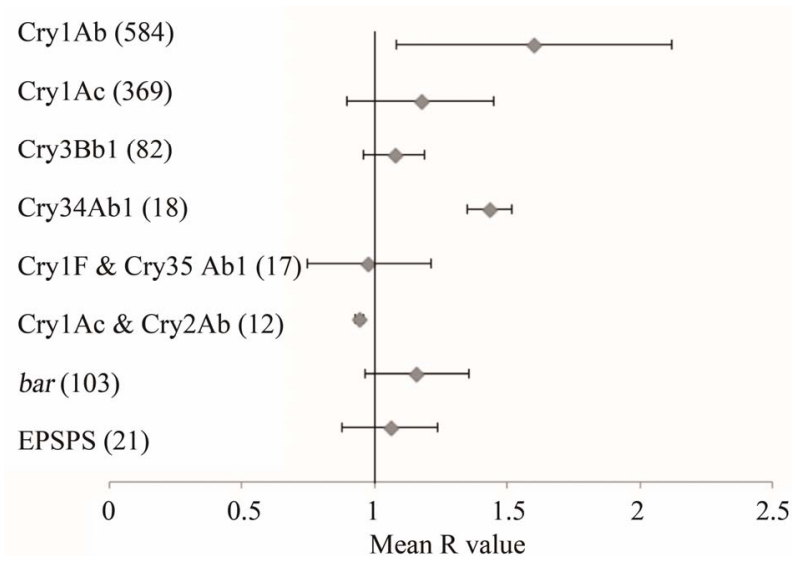

Figure 4. Forest plot of the effect of different genes present in the meta-data on the ratio of GM to conventional environmental indicators. Error bars represent $95 \%$ confidence intervals. All data is independent and the numbers in brackets represent the unique data pairs that comprised the analysis.

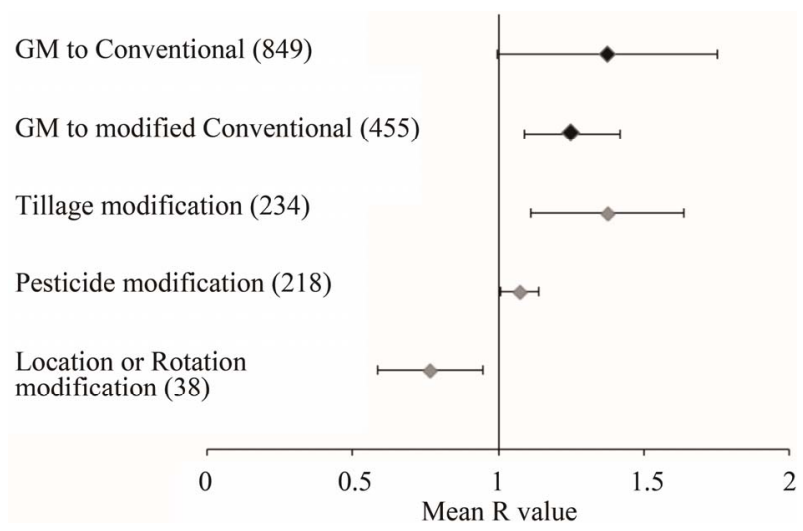

Figure 5. Comparison of the mean ratios for GM to conventional and GM to modified conventional management conditions identified in the studies (larger black diamonds). The mean ratios for modifications to the management in terms of tillage, pesticide and location or rotation data (grey diamonds). The management data is not independent of the GM to modified conventional data, which are presented (larger black diamonds). Error bars indicate 95\% confidence intervals and numbers in brackets the paired data sets used to generate the result. Differences among comparators were not significant based on unbalanced ANOVA assessment of transformed data.

pesticide application); environmental indicators (e.g. arthropods, earthworms, microbiology, weeds); geographic location (e.g. country, continent); or variables specific to the study (e.g. publication year, single or multiyear data).

A number of dummy variables $(1,0)$ were coded to account for the qualitative variables extracted from the studies, in addition the publication year was rebased so that the earliest year (2006) was given a value of 0 and subsequent years coded in increments of 1 (i.e. $2007=1$, $2008=2$ etc. $)$. 


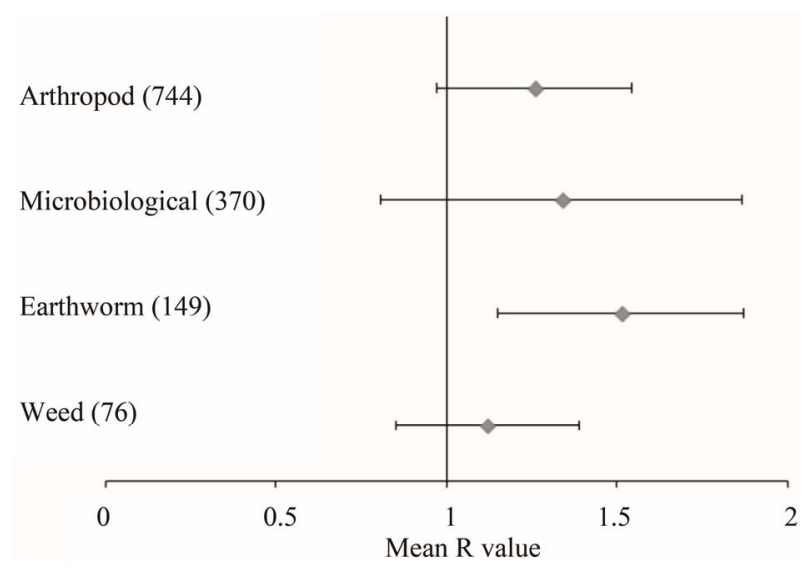

Figure 6. Forest plot of the mean ratio of GM to conventional data for the upper level of environmental indicator categories into which extracted data was assigned based on whether the results pertained to arthropod, microbiological, earthworm or weed science experimentation and analysis. Error bars represent $\mathbf{9 5 \%}$ confidence intervals. Numbers in bracket indicate the number of independent paired data sets that comprised the result.

\section{Results}

\subsection{Studies Found}

19,499 titles hits were recorded using the search statements in the indicated databases of which 4459 titles were retrieved (Figure 1). The number of retrievable titles was restricted on some of the search databases (Table 2) due to exportation limitations. In these instan- ces the hits were ranked by relevance prior to recovery of the maximum number of hits. Review of the 4459 titles from the searches, and an additional 12 novel titles offered by the contacted experts using the study criteria initially resulted in 283 titles being identified as suitable for continuation to abstract screening. The title review was split between members of the review team who independently reviewed a duplicate sample of 157 of the 4459 recovered titles and established $95 \%$ similarity in title selection approach (Kappa 0.85). 14 of the 283 titles were found to have duplicates in the database that once removed resulted in 269 novel titled articles that were selected for screening at abstract.

Imposing the intervention of crop cultivation within the last 5 years would have restricted the review to 10 articles. To increase the potential number of included articles and valid data sets, it was decided to change the intervention to simply include all articles published since January 2006, as had been the basis of the search strategy. Analysis by both reviewers of a sub set of 24 of the abstracts indicated a 92\% similarity (Kappa 0.62) of abstract selection decisions. Following all abstract screening and agreement between the reviewers a total of 102 articles was selected for full review, including 21 articles not captured by the web searches, but identified in the bibliographies of articles selected for full review that matched the selection criteria. Full review of the 102 articles resulted in agreement on inclusion of 43 articles.

Initial review of these 43 articles indicated that there

Table 2. Results of the internet hits for the searches conducted and the offered additional articles contributed from the 14 contacted experts. The number of titles retrieved is indicated, as some of the search databases limited the number of retrievals possible. The number of titles taken through to abstract search as listed as Extracted titles and the totals are presented.

\begin{tabular}{|c|c|c|c|c|}
\hline Search database & Statement modification & Hits & Retrieval & Extracted titles \\
\hline Web of knowledge & None & 158 & 158 & 93 \\
\hline Science direct & None & 3954 & 1000 & 30 \\
\hline Science direct & $\begin{array}{l}\text { Six modifications to syntax and terms } \\
\text { to use advanced search options }\end{array}$ & $\begin{array}{l}28,32,105,15 \\
6 \text { and } 42\end{array}$ & 228 (160 novel) & 17 \\
\hline $\mathrm{CAB}$ direct & None & 9324 & 1000 & 72 \\
\hline $\mathrm{CAB}$ direct & Statement 2 AND 3 & 544 & 544 & 0 \\
\hline COPAC & None & 9804 & 2500 & 1 \\
\hline COPAC & Title word limit & 180 & 180 & 0 \\
\hline Agbioview & Hand search & 3374 & 62 & 57 \\
\hline $\mathrm{BCPC}$ & Hand search & 1415 & 13 & 13 \\
\hline Bibliographies & & & & 21 \\
\hline \multirow[t]{2}{*}{ Expert offered papers } & & & & 12 \\
\hline & Total & 19,499 & 4459 & 316 \\
\hline
\end{tabular}


were 35 individual experimentation platforms, subsequently reported as studies, which covered an accumulated 119 years of field trial seasonal cropping from 15 countries (Australia (1), Canada (5), China (1), Czech Republic (1), Denmark (5), France (6), Germany (5), Hungary (3), India (3), Netherlands (1), Portugal (1), South Africa (1), Spain (1), UK (4) and the USA (9)).

The crops covered in the 43 articles included maize, cotton, oilseed rape (OSR), soy and sugar beet with 31, 9, 4,1 and 2 articles reporting on these crops, respectively. Ten of the articles dealt with herbicide tolerant traits, 29 investigated insect resistance and 4 dealt with both herbicide and insecticide traits (Table 3). This represented 35 separate studies across these articles with $23,9,3,1$ and 1 study on maize, cotton, OSR, soy and sugar beet covered, respectively. The study split between herbicide tolerance, insect resistance and both was 8, 25 and 3, respectively.

\subsection{Study Quality Assessment}

Data presented in the final articles were assessed against the described criteria (section 2.7) and summarised (Table 3). The quality assessment had reviewer assigned quality mean and standard error (in parentheses) scores for no adverse, beneficial and deleterious findings of 3.42 $(0.10), 2.75(0.25)$ and $3(0.71)$, respectively, on the $1-4$ scale where 1 related to valueless and 4 was high quality. The data were not significantly different.

\subsection{Narrative Synthesis}

The author reported findings of the 43 extracted articles indicated that $84.6 \%$ found no adverse effects on the environment from the cultivation of GM, $10.3 \%$ reported a beneficial effect and $5.1 \%$ a deleterious impact. This was equivalent to 89 trial years of no adverse effects, 9 years of beneficial effects and 6 trial years of deleterious impacts across the reported studies.

In the 16 articles dealing with herbicide traits, glufosinate ammonia (bar gene) and glyphosate resistance (EPSPS gene) were represented in 4 and 8 of the 43 final articles, respectively. In the remaining 4 articles pertaining to herbicide tolerant traits the gene or herbicide involved could not be determined. Insecticide resistance genes were not identifiable in 1 ( $3 \%$ of articles dealing with insect resistance) of the articles dealing with these traits. The gene Cryl Ab was reported in $18(46 \%)$ of the articles, Cry1Ac was found in 9 articles (23\%), Cry3Bb1 in 4 articles $(10 \%)$ and Cry2Ac in 2 articles $(5 \%)$. The genes Cry1A, CryIIA, Cry1F, Cry34Ab1 and Cry35AB1 were identified in 1 paper each.

The 119 accumulated years of field data present in the articles covered trials from 1995 to 2009 and was normally distributed (Shapiro-Wilk $p=0.1$ ) from 1998 to
2009 with a range from 1 to 25 trials in 2003 and a mean of 9.67. The average number of years covered by the trials reported within the articles was 2.77 years with a standard deviation of 1.32 , a minimum of 1 , maximum of 7 and a median of 3 .

It had been expected that several potential effect modifiers other than the GM to conventional intervention may have been recorded or examined as part of the reported work. During the initial review of the articles it was noted that effect modifiers pertaining to tillage, pesticide regimes, rotational changes and climatic data were reported in 33\% of the 43 articles. The split of these effect modifiers was: conventional to reduced tillage 5 articles ( $12 \%$ of total), conventional to conventional without pesticides 5 articles (12\%), pesticide and tillage effects 1 paper ( $2 \%$, but no extractable data), rotations 2 articles $(5 \%)$ and climate 1 paper $(2 \%)$.

Four articles from the search and selection process dealt with transgene escapes through out-crossing and pollen flow. These articles represented work on cotton [32], sugar beet [30], maize [55] and OSR [60]. There was no similarity in experimental design or in the nature of the presented data reducing the potential methods of data comparison to a narrative summary of the findings. Three of these four papers did not present a GM to nonGM comparison the exception being Simpson et al. (2006) who used a conventional imidazolinone tolerant variety to compare against glufosinate ammonia and glyphosate tolerant GM varieties [60]. Whilst the imidazolinone outcrossing was lower than the GM varieties, numerous explanations for this observation are given, which lead to the conclusion that more work would be required to understand these differences.

\subsection{Meta Data Analysis}

For meta-data analysis the 43 articles were re-read and data extracted according to the presented criteria (section 2.8). The result of this was that information from 28 of the articles was extracted resulting in 209 lines of $\mathrm{R}$ value data derived from 1339 paired data points.

The overall impression from forest plots of the analysis (Figures 2-6) was that there was a trend toward an increase in the environmental indicators derived from the data sets, in so far as the mean $R$ values were largely $>1$.

Excluding pairs with 0 values had little impact on the number of data points in the meta-data set or on the subsequent analysis. Comparison of data within five of the arthropod articles, in which there were several 0 values for either GM or conventional observations, produced a mean $R$ value of 1.08 for the extracted paired data whilst the mean $\mathrm{R}$ value, based on the totals from the same paper had a mean of 1.02. Whilst omitting values for which there was not a non-zero corresponding 
Table 3. List of the 43 titles grouped by study, crop and modification after initial screening of the full articles. The initial data quality assessment of the articles is presented along with the indication of information potentially extractable for metaanalysis. *NI in the genes column represents that the information was "not indicated" and could not be discerned from other articles relating to the reported trial.

\begin{tabular}{|c|c|c|c|c|c|c|c|c|c|}
\hline First author/ref & Published & $\begin{array}{c}\text { Linked } \\
\text { study }\end{array}$ & $\begin{array}{l}\text { Data } \\
\text { quality }\end{array}$ & Study dates & Country & Crop & Modification & Genes & Potential data \\
\hline Griffiths, B. [20] & 2007 & 1 & 4 & $2002-2005$ & $\begin{array}{l}\text { France, } \\
\text { Denmark }\end{array}$ & Maize & Both & Cry1Ab, bar & $\begin{array}{l}\text { Bacteria to fungi ratios, } \\
\text { nematode }\end{array}$ \\
\hline Krogh, P. [21] & 2007 & 1 & 4 & 2003-2005 & $\begin{array}{l}\text { France, } \\
\text { Denmark }\end{array}$ & Maize & Both & Cry1Ab, bar & Abundance, biomass \\
\hline Cortet, J. [22] & 2007 & 1 & 3 & $2002-2003$ & $\begin{array}{l}\text { France, } \\
\text { Denmark }\end{array}$ & Maize & Insect & Cry1Ab & None \\
\hline Cortet, J. [23] & 2006 & 1 & 4 & $2002-2003$ & $\begin{array}{l}\text { France, } \\
\text { Denmark }\end{array}$ & Maize & Insect & Cry1Ab & $\begin{array}{l}\text { Abundance data } \\
\text { (Table 3) }\end{array}$ \\
\hline Debeljak, M. [24] & 2007 & 1 & 3 & $2002-2003$ & Denmark & Maize & Insect & Cry1Ab & $\begin{array}{l}\text { Earthworm biomass } \\
\text { (Table 1). Abundance of } \\
\text { collembolla (Table 1) }\end{array}$ \\
\hline Heard, M. [25] & 2006 & 2 & 4 & $2000-2002$ & UK & Maize & Herb & NI & $\begin{array}{l}\text { R values, weeds, } \\
\text { invertebrates for fields } \\
\text { and margins }\end{array}$ \\
\hline Firbank, L. [26] & 2006 & 2 & 4 & $2000-2002$ & UK & $\begin{array}{l}\text { Maize, } \\
\text { OSR, Beet }\end{array}$ & Herb & NI & $\begin{array}{l}R \text { values, seedbank } \\
\text { numbers }\end{array}$ \\
\hline Gibbins, D. [27] & 2006 & 2 & 2 & $2000-2002$ & UK & $\begin{array}{l}\text { Maize, } \\
\text { OSR, Beet }\end{array}$ & Herb & NI & $\begin{array}{l}\text { None-weed data of FSE } \\
\text { fitted to proposed bird } \\
\text { diets. }\end{array}$ \\
\hline Balog, A. [4] & 2010 & 3 & 4 & 2001-2003 & Hungary & Maize & Insect & Cry1Ab & $\begin{array}{l}\text { Abundance (Tables } 2 \text { and } \\
\text { 3) and aphid (Table 5) }\end{array}$ \\
\hline Balog, A. [28] & 2011 & 3 & 3 & 2008 & Hungary & Maize & Insect & $\begin{array}{l}\text { Cry1F, } \\
\text { Cry34Ab1, } \\
\text { Cry35Ab1 }\end{array}$ & Abundance in Table 1 \\
\hline Szekeres, D. [29] & 2006 & 3 & 3 & 2001-2003 & Hungary & Maize & Insect & Cry1Ab & $\begin{array}{l}\text { Abundance (Table 1) } \\
\text { species (Table 2) }\end{array}$ \\
\hline Darmency, H. [30] & 2007 & & 4 & $1995-2000$ & France & Beet & Herb & NI & Gene movement \% \\
\hline Cattaneo, N. [31] & 2006 & & 3 & $2002-2003$ & USA & Cotton & Both & Cry1Ac, EPSPS & $\begin{array}{l}\text { Density and species } \\
\text { richness }\end{array}$ \\
\hline Llewellyn, D. [32] & 2007 & & 4 & $2002-2005$ & Australia & Cotton & Both & $\begin{array}{l}\text { Cry1Ac, Cry2Ab, } \\
\text { EPSPS, bar }\end{array}$ & $\begin{array}{l}\text { Gene movement \% into } \\
\text { conventional buffers }\end{array}$ \\
\hline Carriere, Y. [33] & 2009 & & 3 & $2002-2003$ & USA & Cotton & Insect & Cry1Ac & $\begin{array}{l}\text { None-no clear Bt to } \\
\text { Conventional parameters } \\
\text { expressed elsewhere }\end{array}$ \\
\hline Hofs, J. [34] & 2008 & & 4 & 2003-2003 & South Africa & Cotton & Insect & Cry1Ac & $\begin{array}{l}\text { Diversity and abundance } \\
\text { (Tables 1-3) }\end{array}$ \\
\hline Hu, H. [35] & 2009 & & 2 & 2006 & China & Cotton & Insect & Cry1A & $\begin{array}{l}\text { None-time series data. } \\
\text { Raw/mean data } \\
\text { requested. None sent. }\end{array}$ \\
\hline Kumar, K. [36] & 2007 & & 2 & 2002 & India & Cotton & Insect & Cry1Ac, CryIIA & $\begin{array}{l}\text { Abundance (Tables } 1 \\
\text { and 2) }\end{array}$ \\
\hline Mann, R. [37] & 2010 & & 4 & 2004-2005 & India & cotton & Insect & Cry1Ac, Cry2Ab & $\begin{array}{l}\text { Insect (pest and predator) } \\
\text { numbers per plant }\end{array}$ \\
\hline Prasad, N. [38] & 2008 & & 3 & 2005-2006 & India & Cotton & Insect & Cry1Ac & Non-target in Table 1 \\
\hline Torres, J. [39] & 2007 & & 4 & $2002-204$ & USA & Cotton & Insect & Cry1Ac & $\begin{array}{l}\text { Abundance, diversity } \\
\text { indices between bt and } \\
\text { non-bt }\end{array}$ \\
\hline Bourassa, S. [40] & 2010 & & 4 & 2004-2005 & Canada & Maize & Herb & EPSPS & $\begin{array}{l}\text { Density (Table } 1 \text { first } 2 \\
\text { columns) activity density } \\
\text { by rotation (Table } 3 \text { ) }\end{array}$ \\
\hline
\end{tabular}




\section{Continued}

\begin{tabular}{|c|c|c|c|c|c|c|c|c|}
\hline Powell, J. [41] & 2009 & 3 & $2003-2006$ & Canada & Maize & Herb & EPSPS & $\begin{array}{l}\text { Fungal to bacterial } \\
\text { biomass, degradation }\end{array}$ \\
\hline Schier, A. [42] & 2006 & 3 & $2002-2005$ & Germany & Maize & Herb & EPSPS & $\begin{array}{l}\text { None-only RR maize } \\
\text { planted }\end{array}$ \\
\hline $\begin{array}{l}\text { Demaneche, M. } \\
\text { [43] }\end{array}$ & 2008 & 3 & 2007 & France & Maize & Insect & CrylAb & $\begin{array}{l}\text { None-antibiotic resis- } \\
\text { tance levels }\end{array}$ \\
\hline Devare, M. [44] & 2007 & 4 & $2001-2003$ & USA & Maize & Insect & Cry3Bb1 & $\begin{array}{l}\text { Biomass, mineralisation, } \\
\text { nitrification }\end{array}$ \\
\hline Farinos, G. [45] & 2008 & 4 & $2000-2002$ & Spain & Maize & Insect & Cry1Ab & $\begin{array}{l}\text { Richness data in Table } \\
2 \text { and rations in Table } 3\end{array}$ \\
\hline Floate, K. [46] & 2007 & 3 & $2000-2003$ & USA & Maize & Insect & CrylAb & $\begin{array}{l}\text { Means of abundance } \\
\text { where differences } \\
\text { detected (Table 3) }\end{array}$ \\
\hline Frouz, J. [47] & 2008 & 3 & $2002-2004$ & $\begin{array}{l}\text { Czech } \\
\text { Republic }\end{array}$ & Maize & Insect & CrylAb & $\begin{array}{l}\text { Biomass, decomposition } \\
\text { and abundance } \\
\text { (Table 1) }\end{array}$ \\
\hline Gathman, A. [48] & 2006 & 3 & $2001-2003$ & Germany & Maize & Insect & CrylAb & $\begin{array}{l}\text { Ratio of insects between } \\
\text { treatments (Table 3) }\end{array}$ \\
\hline Icoz, I. [49] & 2008 & 3 & $2003-2006$ & USA & Maize & Insect & Cry3Bb1 & $\begin{array}{l}\log 10 \mathrm{CFU} \text { and } \\
\text { enzyme activity }\end{array}$ \\
\hline Lang, A. [12] & 2010 & 3 & $2000-2003$ & Germany & Maize & Insect & Cry $1 \mathrm{Ab}$ & Abundance, biomass, \\
\hline $\begin{array}{l}\text { Miethling-Graff, } \\
\text { R. [50] }\end{array}$ & 2010 & 3 & $2005-2007$ & Germany & Maize & Insect & Cry3Bb1 & None \\
\hline Oliveira, A. [51] & 2008 & 4 & $2003-2004$ & Portugal & Maize & Insect & CrylAb & $\begin{array}{l}\mathrm{cfu} / \mathrm{g}, \text { dehydrogenase, } \\
\text { ATP, nitrogenase }\end{array}$ \\
\hline Priestley, A. [52] & 2009 & 4 & $2003-2004$ & USA & Maize & Insect & Cry1Ab & $\begin{array}{l}\text { Abundance data (Tables } \\
\text { 1, 3,5 and 6) species } \\
\text { data (Table 2) }\end{array}$ \\
\hline Rauschen, S. [53] & 2008 & 4 & $2002-2003$ & Germany & Maize & Insect & Cry $1 \mathrm{Ab}$ & $\begin{array}{l}\text { Ration estimates (Table } \\
\text { 4), abundance (Table 2) }\end{array}$ \\
\hline Rose, R. [54] & 2007 & 3 & $2000-2001$ & USA & Maize & Insect & Cry $1 \mathrm{Ab}$ & $\begin{array}{l}\text { None-data presentation } \\
\text { limits use }\end{array}$ \\
\hline $\begin{array}{l}\text { Van De Wiel, } \\
\text { C. [55] }\end{array}$ & 2009 & 4 & $2006-2007$ & Netherlands & Maize & Insect & CrylAc & $\begin{array}{l}\text { Pollen mediated gene } \\
\text { flow percentages }\end{array}$ \\
\hline Yanni, S. [56] & 2011 & 3 & 2008-2009 & Canada & Maize & Insect & NI & Crop data, lignin, $\mathrm{C} \backslash \mathrm{N}$ \\
\hline Zeilinger, A. [57] & 2010 & 3 & $2005-2006$ & USA & Maize & Insect & Cry1Ab, Cry3Bb1 & $\begin{array}{l}\text { Ash free dry mass of } \\
\text { earthworms }\end{array}$ \\
\hline Gulden, R. [58] & 2009 & 4 & $2000-2006$ & Canada & $\begin{array}{l}\text { Maize, } \\
\text { soy bean }\end{array}$ & Herb & EPSPS & $\begin{array}{l}\text { Ground cover and weed } \\
\text { density }\end{array}$ \\
\hline Lupwayi, N. [59] & 2007 & 3 & $2000-2005$ & Canada & OSR & Herb & EPSPS & Biomass, diversity \\
\hline Simpson, E. [60] & 2006 & 3 & 1998 & UK & OSR & Herb & EPSPS, bar & $\begin{array}{l}\text { Percentage in crops at } \\
\text { distance, data in text. }\end{array}$ \\
\hline
\end{tabular}

data point may have slightly elevated the reported $\mathrm{R}$ values, this observation was not significant $(p=0.68$ in a two tailed $\mathrm{T}$ test) and indicated that the exclusion of pairs with 0 values had little consequence on the sensitivity of the subsequent analysis.

Data of environmental parameters included measures of the following: microbial biomass, bacterial to fungal biomass, heterotrophs, $\mathrm{N}$ mineralisation rates, nitrification rate, biomass $\mathrm{C}$, fungal biomass, fungal abundance, Actinomycetes, dehydrogenase units, ATP, nitrogenase activity, amoeba, flagellates, nematodes, bees, butterflies, predators, spiders, beetles, Carabidae, Staphylindae, Collembolla, Collembolla (epigeic), Collembolla (subterranean), worms data, A. caliginosa, A. longa, A. rosea, A. caliginosa, L. terrestris, Heteroptera, Gastropods, herbivores, parasitoids of herbivores, predators of herbivores, Aphids, A. biguttula, B. tabaci, weed strip analyses, adjacent plant, seedbank density, dicot seedbank, monocot seedbank and ground cover.

Analysis by country of study indicated some exceptions to the general incidence of $\mathrm{R}$ values of $>1$ were observed for trial data from South Africa and Spain $(\mathrm{R}=$ 
Table 4. Regression results for cotton studies (dependent variable $=\mathbf{R}$ value).

\begin{tabular}{|c|c|c|c|c|c|}
\hline & \multicolumn{2}{|c|}{ Coefficients } & \multirow{2}{*}{$\begin{array}{c}\text { Standardised coefficients } \\
\text { Beta }\end{array}$} & \multirow[t]{2}{*}{ t-stat } & \multirow[t]{2}{*}{$p$-value } \\
\hline & $B$ & Std. error & & & \\
\hline Constant & 3.614 & 0.346 & & 10.452 & 0.000 \\
\hline Year $(2006=0)$ & -0.847 & 0.083 & -1.940 & -10.236 & 0.000 \\
\hline Asia dummy (India) & 0.712 & 0.218 & 0.565 & 3.270 & 0.003 \\
\hline Multi-year data dummy & -1.445 & 0.251 & -1.229 & -5.767 & 0.000 \\
\hline Reduced pesticide dummy & -1.747 & 0.314 & -0.558 & -5.567 & 0.000 \\
\hline
\end{tabular}

Number of observation $\quad 32$

Table 5. Regression results for maize studies using country variable (dependent variable = ln $R$ value).

\begin{tabular}{|c|c|c|c|c|c|}
\hline & \multicolumn{2}{|c|}{ Coefficients } & \multirow{2}{*}{$\begin{array}{c}\text { Standardised coefficients } \\
\text { Beta }\end{array}$} & \multirow[t]{2}{*}{ t-stat } & \multirow[t]{2}{*}{$p$-value } \\
\hline & $B$ & Std. error & & & \\
\hline Insect modification dummy & 0.240 & 0.093 & 0.244 & 2.582 & 0.011 \\
\hline France dummy & -0.169 & 0.104 & -0.148 & -1.625 & 0.106 \\
\hline Portugal dummy & -0.268 & 0.143 & -0.158 & -1.875 & 0.063 \\
\hline USA dummy & -0.218 & 0.102 & -0.195 & -2.130 & 0.035 \\
\hline Number of observations & 163 & & & & \\
\hline Adjusted $\mathrm{R}^{2}$ & 0.027 & & & & \\
\hline F value & 2.142 & & & & 0.078 \\
\hline
\end{tabular}

Table 6. Regression results for maize using environmental indicator variable (dependent variable $=\ln R$ value).

\begin{tabular}{|c|c|c|c|c|c|}
\hline & \multicolumn{2}{|c|}{ Coefficients } & \multirow{2}{*}{$\begin{array}{c}\text { Standardised coefficients } \\
\text { Beta }\end{array}$} & \multirow[t]{2}{*}{ t-stat } & \multirow[t]{2}{*}{$p$-value } \\
\hline & $B$ & Std. error & & & \\
\hline Constant & 0.106 & 0.068 & & 1.563 & 0.120 \\
\hline Insect modification dummy & 0.145 & 0.078 & 0.147 & 1.843 & 0.067 \\
\hline Number of observations & 163 & & & & \\
\hline Adjusted $\mathrm{R}^{2}$ & 0.023 & & & & \\
\hline F value & 2.923 & & & & 0.057 \\
\hline
\end{tabular}


0.76 and 0.86 , respectively, Figure 2), cotton with insecticide and herbicide trial effects $(\mathrm{R}=0.89)$, sugar beet $(\mathrm{R}=0.88$, Figure 3$)$, studies involving Cry $1 \mathrm{Ab}$ and Cry2Ac (as found in Bollgard ${ }^{\mathbb{B}}$ II cotton, $\mathrm{R}=0.94$ ) and trials with Cry $1 \mathrm{~F}$ and Cry35Ab1 $(\mathrm{R}=0.98$, Figure 4) and cultivation modifications where location (limited to South Africa) and rotation were included in the trial $(\mathrm{R}=$ 0.74 , Figure 5). Despite these apparent changes in $\mathrm{R}$, unbalanced ANOVA analysis of the natural log transformed data did not detect any significant differences $(p>$ 0.12 in all comparisons) between the indicated study factors. These unbalanced ANOVA assessments of the various study factors also served as a sensitivity analysis of the data set.

To attempt to determine if the meta-data set was similar to an $\mathrm{R}$ value of 1 , which would have indicated no change from the adoption of GM, the data was run against a dummy set of $R$ values equal to 1 . Chi squared analysis showed that there was a significant difference between the two set $\left(\chi^{2}=622, \mathrm{df}=208, p<0.001\right)$. A two tailed $\mathrm{T}$ test of the data also indicated a significant difference $(p<0.01)$ with the meta-data having a mean $\mathrm{R}$ value of 1.31 .

Within the data set there was significant heterogeneity $(Q=1134, \mathrm{df}=208, p<0.001)$, which was explored further using regression analysis in SPSS with the recorded environmental factors as independent variables.

Initial model specifications including all crop types were estimated within the model, but no significant explanatory variables were found for the $\mathrm{R}$ values. The next step was to explore models for individual crop types: models for beet $(\mathrm{n}=3)$, maize and soy $(\mathrm{n}=8)$ and oilseed rape $(\mathrm{n}=3)$ were not estimated due to low numbers of observations.

Cotton, with $n=32$, was subjected to regression analysis and the results presented (Table 4). The variables were all significant $(p<0.01)$ as was the regression as a whole ( $p$ value of the $F$ value), the adjusted $R^{2}$ value indicated that the variables explained $77 \%$ of the observed variation. The negative coefficient for the year variable indicated that more recently published studies report lower $\mathrm{R}$ values, however, the extent to which this reflects more recently conducted studies is not clear. Studies reporting $\mathrm{R}$ values over multiple years (as opposed to single years) also show reduced $\mathrm{R}$ values. The positive value of the Asia dummy indicated that studies undertaken in India showed a more favourable environmental outcome with a $R$ value of $>1$. Where the description of the conventional system was recorded as having been modified through the reduced use of pesticides and the reduced pesticide dummy was given a value of 1 ; the negative sign of the corresponding coefficient was as expected and reflected the higher environmental outcome (all based on arthropod data) under the conventional sys- tem with reduced pesticide, thus reducing any relative advantage of GM.

Comparison of the standardised coefficients indicated that publication year has the greatest influence in $\mathrm{R}$ value followed by multi-year data, country of study and modifier had opposite effects of similar magnitude. These results indicated that study related factors explain more of the variation in environmental outcome than both study location and what the GM is compared to.

Maize had the highest number of observations ( $\mathrm{n}=$ 163 ) in this dataset and regression analysis was undertaken (Table 5), however, despite the higher number of observations we were unable to estimate a model that performed as well as that for cotton. The overall model had a low goodness of fit $\left(\mathrm{R}^{2}=2.7 \%\right)$, but was significant $(p<0.10)$. This suggests that there remain important variables explaining $R$, but that these are not present in the reported experimental literature as they are either not associated with the experimentation or not recognised as being significant for study inclusion. It should be noted that the dependent variable used for the maize model was the natural logarithm of the $\mathrm{R}$ value, this transformation was used to reduce the effect of a skewed distribution of $\mathrm{R}$ values that resulted from a small number of outliers. Insect resistance was analysed with inclusion of an insect modification dummy variable, which had a positive coefficient indicating this modification, rather than herbicide tolerance, resulted in more positive environmental outcomes (i.e. higher $\mathrm{R}$ values). This was also the most influential variable as demonstrated by the standardised coefficient. Alternate analysis that considered specific genes, rather than the broader trait, did not produce significant results. The remaining significant variables all related to country specific effects, with the negative coefficients in each case indicating lower $\mathrm{R}$ values in each of these countries.

The coefficient for the France dummy was marginally insignificant at $p=0.10$, but removal of this variable from the model reduced overall model performance and significance. These results might be interpreted as country level effects as the studies for each of these countries involved the same trait (insecticide), but showed an opposite effect to that trait and the same gene (Cry1Ab), which in itself was not significant. However, the studies in each of these countries primarily used microbiological environmental indicators. A simpler model for maize, where environmental indicator was used in place of country variables (Table 6) performed better in terms of overall significance (0.057 vs. 0.078 ) and suggests that what might have been interpreted as a country level effect was in fact due to the choice of the environmental indicator used to determine R. In this case the negative coefficient showed that studies using microbiological indicators produce a reduced value of $\mathrm{R}$. The 
standardised coefficient indicates that this effect is stronger than that due to trait.

The results of the regression analysis indicate that there is no standard model to explain variation in environmental outcome. However, in both the cotton and maize models, variables relating to the design of the study have a significant effect on outcome.

\section{Discussion}

Narrative analysis of all 43 of the extracted articles indicated that most stated either no adverse effects or positive environmental benefits from GM adoption, but it is perhaps worth considering this point from those that reported deleterious impacts. In total, two of the 43 articles reported deleterious environmental impacts of GM adoption. Five $\%$ is often taken as the point at which observations become significant and so, from the narrative analysis of the author reported outcomes of the articles, there was evidence that deleterious environmental impacts from GM cultivation were occurring by mechanisms other than chance. However, when reviewed by study this value reduced to only one of the 35 studies reported in the selected articles, with 26 reporting no adverse impact, four beneficial outcomes and four with no author indicated preference for the outcome. This analysis represents a crude interpretation of author opinions' and hence the need for more rigorous analysis.

\subsection{Evidence of Environmental Impact}

The targeted approach to peer reviewed and grey literature recovery was deemed successful in that none of the final material was found to be worthless during the qualitative assessment. Despite the effort exerted in the grey literature searches, none of the final 43 articles were a result of this undertaking. Theories for this were discussed and the general consensus was that because the target audience for grey literature is more diverse the content is generally less specific or in-depth than the peer reviewed literature.

The number of articles finally selected is small given the subject area and the content of the articles and the cropping areas covered is also limited in the number of crops identified and the countries covered. There are currently 29 countries growing 12 commercial GM crops [1] and yet we identified articles covering only 15 countries and 5 crops. Differences in the crops detected may be partially due to the geographical restrictions on the commercialisation of crops like poplar, tomato, sweet pepper, squash and papaya. Another potential reason for this discrepancy is that we restricted our analysis to articles published in the past 5 years, which may have excluded some of the crops on the grounds of when the work on them was published. This may have been further exasperated by our restriction to articles published in English, which may also have attributed to the country difference, but this may have occurred due to the rapid adoption of GM in developing countries that is being observed [1] and that these countries may be looking elsewhere for scientific guidance [61].

Papers on pollen transfer between genetically modified crops and either wild or cropped compatible recipeents made it through the search and review process, but were dealt with independently of the other articles and data because they did not present a GM to non-GM comparison with one exception [60]. The aspect of isolation distances was addressed in the cotton and maize work, which is significant from an EU standpoint as thresholds dictate the requirement for labelling. Both papers indicate that the tested buffer or isolation distances of $20 \mathrm{~m}$ for cotton [32] and $25 \mathrm{~m}$ for maize [55] would prevent pollen mediated gene flow from exceeding the $0.9 \%$ labelling threshold. However, the authors note that changes in field sizes, extreme weather conditions, increased pollinator presence, areas of open ground and legislative threshold changes all require consideration. Pollen flow from sugar beet was reported as accounting for $0.4 \%$ of the resistant seeds that subsequently developed [30]. Pollen movement was recorded over $277 \mathrm{~m}$, which was greater than that observed in the cotton and maize work, but the greatest issue with transgene escape came from sugar beet bolters appearing in the following crop, which implies that suitable management, either mechanical or herbicidal, would be a required to restrict gene flow [30].

A number of issues were identified within the papers that can have a further impact on the extent of pollen movement in the environment and three of the four papers identified the need for further study either before or when GM cropping status changes. The limited number of studies relating to GM pollen flow issues, identified with the methodology used in this review, meant that more critical appraisal of the issue of pollen transfer was not possible and would be better achieved through a more targeted systematic review of pollen flow from specific crops without time bound restrictions.

The systematic review of environmental indicators was undertaken using a ratio approach to data extraction and analysis, similar to those undertaken in previous medical systematic reviews [62]. Given the wide range of potential environmental indicators available within the selected articles this approach was also seen as one that would allow for direct comparison across all possible data sets providing reported data could be paired according to one of the prescribed environmental comparators and that neither number in the pair was zero. Extracting the data in the way described meant that any positive response in an environmental indicator under GM cultivation would result in a value of more than 1 , whilst a 
reduction would produce a value of less than 1 and no change a value of 1 .

In order to determine if the effect of GM adoption had no impact upon the environmental indicators, a dummy set of values of 1 was constructed, the theory being that if the GM over conventional ratios were statistically similar to 1 then there was no change in the reported environmental parameters as a result of GM adoption over the conventional system. Results of the analysis indicated that the difference was significant $(p<0.01)$ with the GM adoption producing a mean ratio of 1.31 . This represented an increase above the potential value of 1 , which would have indicated no change, however, this significant increase in the effect of GM on the environment does have to be treated with caution due to the method by which it was derived and because at present it is not possible to associate an increase in most, if not all, environmental parameters with an improvement in fitness or health of the ecosystem. In order to attempt to resolve which of the reported and recorded comparators could potentially be causing a shift in measured environmental parameters forest plots were produced and univariate meta-analysis undertaken.

\subsection{Reasons for Variation in Impact}

The results of the regression analysis indicated that there is no standard model to explain variation in environmental outcome. However, in both the cotton and maize models, variables relating to the design of the study had a significant effect on outcome, although the significance of trait or gene were often absent from these.

Analysis of the data, represented in the forest plots (Figures 2-6), did not detect any significant differences.

The univariate meta-analysis when modelled for cotton produced an adjusted $\mathrm{R}^{2}$ value, which indicated that variables explained $77 \%$ of the observed variation. Comparison of the standardized coefficients indicated that publication year had the greatest influence in $\mathrm{R}$ value followed by multi-year data collection, with location and modifier comparators having opposite effects of similar magnitude (Table 4). These results indicate that study related factors, which included: crop, field number, field size, trait, genes and season or seasonal in the model, explained more of the variation in environmental outcome than both study location and what GM is compared to. The effect of year is potentially due to improvements in data generation and handling techniques over the reported years. Multi-seasonal trials are likely to offer improved accuracy and more robust data than single season experiments as they capture the effects of seasonal environmental perturbations between trials and experiments. Whilst the observation that modification of the cropping system had only a slight effect on the variation, it is worth mentioning that there was no explanation from the trait or gene insertion. The inferred meaning from this is that management is likely to be more important in terms of environmental impact than the presence of the GM as has been previously reported [63].

This modelling exercise was repeated for maize, but the $\mathrm{R}^{2}$ value was 2.7 thus explaining less than $3 \%$ of the variation in the data despite making up the biggest number of data points $(n=163)$. The remaining significant variables all related to country specific effects that generally lowered the $\mathrm{R}$ value, indicating that GM adoption had reduced the measured environmental variables for maize in certain countries. Why the maize data behaved in this way is largely unclear, but could be a result of the use of hybrids specific for the various regions of cultivation or due to differences in cultivation practices and differences in growing season lengths and climate of the countries represented in the database. Considering the nature of the modification across all plant types it was found that insect modification had a positive coefficient, which indicated that insect resistance modification rather than herbicide tolerance resulted in more positive environmental outcomes.

\subsection{Review Limitations}

Despite attempts to conduct a robust and thorough review utilizing systematic process, there are accepted limitations in this review. Firstly, the posed question, which was stipulated by the project funder, was too broad. Addressing the question to a specific crop, expressing a specific trait and focusing on a specific envinronmental indicator would better address whether the changes in GM adoption were beneficial or deleterious with regard to that specific crop and trait, rather than just resulting in a significant change. This more focused approach has been the aim of other recent systematic reviews $[3,5,18]$. Another alternative would have been to have used what is still seen as many as being the best environmental indicator, yield. However, yield was rarely reported in the examined articles.

Searches were limited to the English language and one possible improvement would be to include other languages if this process was to be repeated.

We attempted here to provide an overview of all commercial traits and crops limited only by the caveats of field data and publication since 2006. Whilst this restricted the articles to 43 , those that may have been missed or omitted might have been crucial in strengthening some aspects of the review. It was noted that there was a lack of multiple gene insertion events and stacked trait data in the extracted articles. Stacked traits are on the increase and accounted for $41 \%$ of all commercial GM plantings in the USA in 2010 [1]. Explanation for this may well be in the fact that despite targeting articles published 
between 2006 to 2011, the field trial data presented in the extracted literature peaked in 2003, the year Cry2Ab was added to Cry1Ac in commercial cotton [64] and when herbicide resistance was still entering the market.

Improvement in the analysis of the impact and the direction of the impact of the environmental data considered in this review would only be possible if the data extracted was comparable. This might be achievable through limitation to a specific species data or enzymatic test, or if new statistical techniques were developed for handling non-comparable environmental data. Additionally, the limits to qualifiers, which included: only field-released GM traits, only with some scale of field cultivation, and only published since 2006 imposed further limitations to the review. These limitations included altering the breadth of the review to a more immediate or short-term impact focus on currently grown GM crops, which may have contributed to a lack of coverage of the number of available traits and commercial cultivars, and a bias towards only a sub set of the countries due to both publication original and regions where GM crops are approved for cultivation.

Authors whose articles made the final 43, but from whose published articles data extraction was not possible were contacted, but time constraints on the delivery of the project meant that at the point of undertaking analysis and reporting only one had provided supplemental data files.

The search of the grey literature was not productive in terms of producing material that made it through the screening process and therefore added nothing to subsequent analysis. Similarly, the use of search engines to identify suitable material was also found to be problematic and excluded. It is likely that there are sources of information pertinent to a review of this nature within the grey and on-line literature, but the expenditure of time and effort to find it was not available within the bounds of this project. Subsequent reviews should either allow for this or develop a separate search terminology strategy for use with search engines.

\section{Conclusions}

The review process produced 43 articles for analysis from over 19000 initial web hits generated in database searches. Of the 43 articles only 28 gave rise to data suitable for development of a data base. The dataset covered a limited geographical representation of nations involved in GM adoption and presented a bias toward the dominance of certain crop types and traits. Despite this, analysis indicated that GM adoption caused a significant shift in the ratio of the reported environmental parameters with a significant increase in environmental indicators with the adoption of GM from an expected ratio of 1, indicating no difference, to 1.31 . However, due to the limitations and diversity of the environmental indicators ex- tracted from the articles it is impossible to determine if this shift represents a deleterious or beneficial environmental change.

There was a lack of statistically significant difference between the extracted study outcomes and environmental indicators for beneficial and deleterious environmental changes do not currently exist that could be applied to the scale attempted in this review. However, narrative analysis of the 35 studies from 43 identified articles indicated that 26 studies reported no adverse effects on the environment from the cultivation of GM, four reported a beneficial effect and one a deleterious impact. The narrative analysis presents an indication of a lack of negative impact from GM adoption.

In order to establish the factors responsible for the variation observed within the data set, meta-analysis was conducted. The results of the regression analysis indicate that there was no standard model to explain variation in environmental outcome. In models for both cotton and maize, variables relating to the design of the study had a significant effect on outcome, but these variables were not related to trait or gene insertion and were generally either year, country specific or due to changes in cultivation practice in origin. It is of note that the model for cotton accounted for $77 \%$ of the observed variation, but for maize less than $3 \%$ of the variation was accounted for. Analysis also indicated that longer studies had a reduced $\mathrm{R}$ value, which could be taken as indication that long term beneficial or deleterious impacts of GM on environmental indicators are likely to lessen over time compared to any observed in the short term.

The conclusion of this study, which reviewed the literature published since January 2006 on the environmental impact of GM crops, is that GM adoption has had an impact on its environment, but that the cause of this impact is not due to the genetic modification and it is generally interpreted as having no adverse effects..

\section{Acknowledgements}

This work was funded as part of a UK Department for Environment Food and Rural Affairs grant (CB0302). It was independently undertaken by SRUC and Innovation Management. Neither SRUC nor Innovation Management have ventures or undertakings that would profit from work pertaining to views either for or against the adoption of GM. Additionally neither organization has links with external companies nor other bodies that could profit from this review or attempted to influence its outcome. In this regard this work represents an unbiased interpretation of the available data and the views expressed in the paper are those of the authors and do not represent Defra policy. During components of this review additional statistical advice was provided by $\mathrm{Dr}$ Gareth Hughes. 


\section{REFERENCES}

[1] C. James, "Global Status of Commercialized Biotech/GM Crops," ISAAA, Brief 42, Ithaca, 2010.

[2] D. A. Andow, G. L. Lovei and S. Arpaia, "Ecological Risk Assessment for Bt Crops," Nature Biotechnology, Vol. 24, No. 7, 2006, pp. 749-751. doi:10.1038/nbt0706-749

[3] M. Marvier, C. McCreedy, J. Regetz and P. Kareiva, "A Meta-Analysis of Effects of Bt Cotton and Maize on Nontarget Invertebrates," Science, Vol. 316, No. 5830, 2007, pp. 1475-1477. doi:10.1126/science. 1139208

[4] A. Balog, J. Kiss, D. Szekeres, A. Szenasi and V. Marko, "Rove Beetle (Coleoptera: Staphylinidae) Communities in Transgenic Bt (MON810) and near Isogenic Maize," Crop Protection, Vol. 29, No. 6, 2010, pp. 567-571. doi:10.1016/j.cropro.2009.12.020

[5] A. Ricroch, J. Berge and M. Kuntz, "Is the German Suspension of MON810 Maize Cultivation Scientifically Justified?" Transgenic Research, Vol. 19, No. 1, 2010, pp. 1-12. doi:10.1007/s11248-009-9297-5

[6] G. Brookes and P. Barfoot, "GM Crops: The Global Economic and Environmental Impact - The First Nine Years 1996-2004," AgBioForum, Vol. 8, No. 2-3, 2005, pp. 187-196.

[7] G. P. Fitt, "Have Bt Crops Led to Changes in Insecticide Use Patterns and Impacted IPM?" Integration of InsectResistant Genetically Modified Crops within IPM Programs, Vol. 5, 2008, pp. 303-328.

[8] G. Brookes and P. Barfoot, "GM Crops: The First Ten Years-Global Socio-Economic and Environmental Impacts," ISAAA, Ithaca, 2006.

[9] O. G. G. Knox, G. A. Constable, B. Pyke and V. V. S. R. Gupta, "Environmental Impact of Conventional and Bt Insecticidal Cotton Expressing One and Two Cry Genes in Australia," Australian Journal of Agricultural Research, Vol. 57, No. 5, 2006, pp. 501-509. doi:10.1071/AR05366

[10] H. J. Beckie, K. N. Harker, L. M. Hall, S. I. Warwick, A. Legere, P. H. Sikkema, G. W. Clayton, A. G. Thomas, J. Y. Leeson, G. Seguin-Swartz and M. J. Simard, "A Decade of Herbicide-Resistant Crops in Canada," Canadian Journal of Plant Science, Vol. 86, No. 4, 2006, pp. 12431264.

[11] G. A. Kleter, R. Bhula, K. Bodnaruk, E. Carazo, A. S. Felsot, C. A. Harris, A. Katayama, H. A. Kuiper, K. D. Racke, B. Rubin, Y. Shevah, G. R. Stephenson, K. Tanaka, J. Unsworth, R. Wauchope and S. S. Wong, "Altered Pesticide Use on Transgenic Crops and the Associated General Impact from an Environmental Perspective," Pest Management Science, Vol. 63, No. 11, 2007, pp. 1107-1115. doi:10.1002/ps.1448

[12] A. Lang and M. Otto, "A Synthesis of Laboratory and Field Studies on the Effects of Transgenic Bacillus Thuringiensis (Bt) Maize on Non-Target Lepidoptera," Entomologia Experimentalis et Applicata, Vol. 135, No. 2, 2010, pp. 121-134. doi:10.1111/j.1570-7458.2010.00981.x

[13] F. Widmer, "Assessing Effects of Transgenic Crops on
Soil Microbial Communities," Green Gene Technology: Research in an Area of Social Conflict, Vol. 107, 2007, pp. 207-234. doi:10.1007/10 $2007 \quad 047$

[14] G. Brookes and P. Barfoot, "GM Crops: Global SocioEconomic and Environmental Impacts 1996-2009,” PG Economics Ltd., Dorchester, 2011.

[15] G. L. Lovei, D. A. Andow and S. Arpaia, "Transgenic Insecticidal Crops and Natural Enemies: A Detailed Review of Laboratory Studies," Environmental Entomology, Vol. 38, No. 2, 2009, pp. 293-306. doi: $10.1603 / 022.038 .0201$

[16] G. B. Stewart, C. F. Coles and A. S. Pullin, "Applying Evidence-Based Practice in Conservation Management: Lessons from the First Systematic Review and Dissemination Projects," Biological Conservation, Vol. 126, No. 2, 2005, pp. 270-278. doi:10.1016/j.biocon.2005.06.003

[17] Centre for Evidence-Based Conservation,"Guidelines for Systematic Review in Environmental Management," Version 4.0., 2010.

[18] L. Wolfenbarger, S. E. Naranjo, J. G. Lundgren, R. J. Bitzer and L. S. Watrud, "Bt Crop Effects on Functional Guilds of Non-Target Arthropods: A Meta-Analysis," PLos One, Vol. 3, No. 5, 2008, p. e2118. doi: $10.1371 /$ journal.pone.0002118

[19] S. Lewis and M. Clarke, "Forest Plots: Trying to See the Wood and the Trees," BMJ, Vol. 322, No. 7300, 2001, pp. 1479-1480. doi:10.1136/bmj.322.7300.1479

[20] B. S. Griffiths, S. Caul, J. Thompson, A. N. Birch, J. Cortet, M. N. Andersen and P. H. Krogh, "Microbial and Microfaunal Community Structure in Cropping Systems with Genetically Modified Plants," Pedobiologia, Vol. 51, No. 3, 2007, pp. 195-206.

doi:10.1016/j.pedobi.2007.04.002

[21] P. H. Krogh, B. Griffiths, D. Demsar, M. Bohanec, M. Debeljak, M. N. Andersen, C. Sausse, A. N. Birch, S. Caul, M. Holmstrup, L. H. Heckmann and J. Cortet, "Responses by Earthworms to Reduced Tillage in Herbicide Tolerant Maize and Bt Maize Cropping Systems," Pedobiologia, Vol. 51, No. 3, 2007, pp. 219-227. doi:10.1016/j.pedobi.2007.04.003

[22] J. Cortet, B. S. Griffiths, M. Bohanec, D. Demsar, M. N. Andersen, S. Caul, A. N. E. Birch, C. Pernin, E. Tabone, A. de Vaufleury, X. Ke and P. H. Krogh, "Evaluation of Effects of Transgenic Bt Maize on Microarthropods in a European Multi-Site Experiment," Pedobiologia, Vol. 51, No. 3, 2007, pp. 207-218. doi:10.1016/j.pedobi.2007.04.001

[23] J. Cortet, M. N. Andersen, S. Caul, B. Griffiths, R. Joffre, B. Lacroix, C. Sausse, J. Thompson and P. H. Krogh, "Decomposition Processes under Bt (Bacillus thuringiensis) Maize: Results of a Multi-Site Experiment," Soil Biology and Biochemistry, Vol. 38, No. 1, 2006, pp. 195-199. doi:10.1016/j.soilbio.2005.04.025

[24] M. Debeljak, J. Cortet, D. Demsar, P. H. Krogh and S. Dzeroski, "Hierarchical Classification of Environmental Factors and Agricultural Practices Affecting Soil Fauna under Cropping Systems Using Bt Maize," Pedobiologia, Vol. 51, No. 3, 2007, pp. 229-238. doi:10.1016/i.pedobi.2007.04.009 
[25] M. Heard, S. Clark, P. Rothery, J. Perry, D. Bohan, D. Brooks, G. Champion, A. Dewar, C. Hawes, A. Haughton, M. May, R. Scott, R. Stuart, G. Squire and L. Firbank, "Effects of Successive Seasons of Genetically Modified Herbicide-Tolerant Maize Cropping on Weeds and Invertebrates," Annals of Applied Biology, Vol. 149, No. 3, 2006, pp. 249-254.

doi:10.1111/j.1744-7348.2006.00091.x

[26] L. G. Firbank, P. Rothery, M. J. May, S. J. Clark, R. J. Scott, R. C. Stuart, C. W. H. Boffey, D. R. Brooks, G. T. Champion, A. J. Haughton, C. Hawes, M. S. Heard, A. M. Dewar, J. N. Perry and G. R. Squire, "Effects of Genetically Modified Herbicide-Tolerant Cropping Systems on Weed Seedbanks in Two Years of Following Crops," Biology Letters, Vol. 2, No. 1, 2006, pp. 140-143. doi:10.1098/rsbl.2005.0390

[27] D. W. Gibbons, D. A. Bohan, P. Rothery, R. C. Stuart, A. J. Haughton, R. J. Scott, J. D. Wilson, J. N. Perry, S. J. Clark, R. J. Dawson and L. G. Firbank, "Weed Seed Resources for Birds in Fields with Contrasting Conventional and Genetically Modified Herbicide-Tolerant Crops," Proceedings of the Royal Society B-Biological Sciences, Vol. 273, No. 1596, 2006, pp. 1921-1928. doi:10.1098/rspb.2006.3522

[28] A. Balog, A. Szenasi, D. Szekeres and Z. Palinkas, "Analysis of Soil Dwelling Rove Beetles (Coleoptera: Staphylinidae) in Cultivated Maize Fields Containing the $\mathrm{Bt}$ Toxins, Cry34/35Ab1 and Cry1F x Cry34/35Ab1," Biocontrol Science and Technology, Vol. 21, No. 3, 2011, pp. 293-297. doi:10.1080/09583157.2010.545104

[29] D. Szekeres, F. Kadar and J. Kiss, "Activity Density, Diversity and Seasonal Dynamics of Ground Beetles (Coleoptera: Carabidae) in Bt-(MON810) and in Isogenic Maize Stands," Entomologica Fennica, Vol. 17, No. 3, 2006, pp. 269-275.

[30] H. Darmency, Y. Vigouroux, T. G. Garambe, M. RichardMolard and C. Muchembled, "Transgene Escape in Sugar Beet Production Fields: Data from Six Years farm Scale Monitoring," Environmental Biosafety Research, Vol. 6, No. 3, 2007, pp. 197-206. doi:10.1051/ebr:2007007

[31] M. G. Cattaneo, C. Yafuso, C. Schmidt, C. Y. Huang, M. Rahman, C. Olson, C. Ellers-Kirk, B. J. Orr, S. E. Marsh, L. Antilla, P. Dutilleul and Y. Carriere, "Farm-Scale Evaluation of the Impacts of Transgenic Cotton on Biodiversity, Pesticide Use, and Yield," Proceedings of the $\mathrm{Na}$ tional Academy of Sciences of the United States of America, Vol. 103, No. 20, 2006, pp. 7571-7576. doi: $10.1073 /$ pnas.0508312103

[32] D. Llewellyn, C. Tyson, G. Constable, B. Duggan, S. Beale and P. Steel, "Containment of Regulated Genetically Modified Cotton in the Field," Agriculture, Ecosystems \& Environment, Vol. 121, No. 4, 2007, pp. 419-429. doi:10.1016/j.agee.2006.11.019

[33] Y. Carriere, C. Ellers-Kirk, M. G. Cattaneo, C. M. Yafuso, L. Antilla, C. Huang, M. Rahman, B. J. Orr and S. E. Marsh, "Landscape Effects of Transgenic Cotton on NonTarget Ants and Beetles," Basic and Applied Ecology, Vol. 10, No. 7, 2009, pp. 597-606. doi:10.1016/j.baae.2008.10.010

[34] J. Hofs, A. Schoeman and J. Pierre, "Diversity and Abun- dance of Flower-Visiting Insects in Bt and Non-Bt Cotton Fields of Maputaland (KwaZulu Natal Province, South Africa)," International Journal of Tropical Insect Science, Vol. 28, No. 4, 2008, pp. 211-219. doi:10.1017/S1742758408201682

[35] H. Y. Hu, X. X. Liu, Z. W. Zhao, J. G. Sun, Q. W. Zhang, X. Z. Liu and Y. Yu, "Effects of Repeated Cultivation of Transgenic Bt Cotton on Functional Bacterial Populations in Rhizosphere Soil," World Journal of Microbiology \& Biotechnology, Vol. 25, No. 3, 2009, pp. 357-366. doi:10.1007/s11274-008-9899-8

[36] K. R. Kumar, G. Chandrasehar and S. Ayyappan, "Assessment of Arthropod Communities in Transgenic and Conventional Cotton in Kancheepuram District, Tamil Nadu," Journal of Ecobiology, Vol. 19, No. 3, 2007, pp. 201-207.

[37] R. S. Mann, R. S. Gill, A. K. Dhawan and P. S. Shera, "Relative Abundance and Damage by Target and NonTarget Insects on Bollgard and BollgardII Cotton Cultivars," Crop Protection, Vol. 29, No. 8, 2010, pp. 793-801. doi:10.1016/j.cropro.2010.04.006

[38] N. V. V. S. Prasad and N. H. Rao, "Field Evaluation of Bt Cotton Hybrids against Insect Pest Complex under Rainfed Conditions," Indian Journal of Entomology, Vol. 70, No. 4, 2008, pp. 330-336.

[39] J. Torres and J. Ruberson, "Abundance and Diversity of Ground-Dwelling Arthropods of Pest Management Importance in Commercial Bt and Non-Bt Cotton Fields," Annals of Applied Biology, Vol. 150, No. 1, 2007, pp. 2739. doi:10.1111/j.1744-7348.2006.00087.x

[40] S. Bourassa, H. Carcamo, J. Spence, R. Blackshaw and K. Floate, "Effects of Crop Rotation and Genetically Modified Herbicide-Tolerant Corn on Ground Beetle Diversity, Community Structure, and Activity Density," Canadian Entomologist, Vol. 142, No. 2, 2010, pp. 143-159. doi:10.4039/n09-017

[41] J. R. Powell, D. J. Levy-Booth, R. H. Gulden, W. L. Asbil, R. G. Campbell, K. E. Dunfield, A. S. Hamill, M. M. Hart, S. Lerat, R. E. Nurse, K. Pauls, P. H. Sikkema, C. J. Swanton, J. T. Trevors and J. N. Klironomos, "Effects of Genetically Modified, Herbicide-Tolerant Crops and Their Management on Soil Food Web Properties and Crop Litter Decomposition," Journal of Applied Ecology, Vol. 46, No. 2, 2009, pp. 388-396. doi:10.1111/j.1365-2664.2009.01617.x

[42] A. Schier, "Field Study on the Occurrence of Ground Beetles and Spiders in Genetically Modified, Herbicide Tolerant Corn in Conventional and Conservation Tillage Systems," Journal of Plant Diseases and Protection, 2006, pp. 101-113.

[43] S. Demaneche, H. Sanguin, J. Pote, E. Navarro, D. Bernillon, P. Mavingui, W. Wildi, T. M. Vogel and P. Simonet, "Antibiotic-Resistant. Soil Bacteria in Transigenic Plant Fields," Proceedings of the National Academy of Sciences of the United States of America, Vol. 105, No. 10, 2008, pp. 3957-3962. doi:10.1073/pnas.0800072105

[44] M. Devare, R. Londono and J. Thies, "Neither Transgenic Bt Maize (MON863) nor Tefluthrin Insecticide Adversely Affect Soil Microbial Activity or Biomass: A 3-Year Field Analysis," Soil Biology \& Biochemistry, Vol. 39, 
No. 8, 2007, pp. 2038-2047. doi:10.1016/j.soilbio.2007.03.004

[45] G. P. Farinos, M. de la Poza, P. Hernandez-Crespo, F. Ortego and P. Castanera, "Diversity and Seasonal Phenology of Aboveground Arthropods in Conventional and Transgenic Maize Crops in Central Spain," Biological Control, Vol. 44, No. 3, 2008, pp. 362-371.

doi:10.1016/j.biocontrol.2007.11.007

[46] K. D. Floate, H. A. Círcamo, R. E. Blackshaw, B. Postman and S. Bourassa, "Response of Ground Beetle (Coleoptera: Carabidae) Field Populations to Four Years of Lepidoptera-Specific Bt Corn Production," Environmental Entomology, Vol. 36, No. 5, 2007, pp. 1269-1274. doi:10.1603/0046-225X(2007)36[1269:ROGBCC]2.0.CO :2

[47] J. Frouz, D. Elhottova, M. Helingerova and F. Kocourek, "The Effect of Bt-Corn on Soil Invertebrates, Soil Microbial Community and Decomposition Rates of Corn PostHarvest Residues under Field and Laboratory Conditions," Journal of Sustainable Agriculture, Vol. 32, No. 4, 2008, pp. 645-655. doi:10.1080/10440040802395098

[48] A. C. H. I. Gathmann, L. U. D. G. Wirooks, L. A. Hothorn, D. E. T. L. Bartsch and I. N. G. O. Sshuphan, "Impact of Bt Maize Pollen (MON810) on Lepidopteran Larvae Living on Accompanying Weeds," Molecular Ecology, Vol. 15, No. 9, 2006, pp. 2677-2685. doi:10.1111/j.1365-294X.2006.02962.X

[49] I. Icoz, D. Saxena, D. A. Andow, C. Zwahlen and G. Stotzky, "Microbial Populations and Enzyme Activities in Soil in Situ under Transgenic Corn Expressing Cry Proteins from Bacillus thuringiensis," Journal of Environmental Quality, Vol. 37, No. 2, 2008, pp. 647-662. doi:10.2134/jeq2007.0352

[50] R. Miethling-Graff, S. Dockhorn and C. C. Tebbe, "Release of the Recombinant Cry3Bb1 Protein of Bt Maize MON88017 into Field Soil and Detection of Effects on the Diversity of Rhizosphere Bacteria," European Journal of Soil Biology, Vol. 46, No. 1, 2010, pp. 41-48. doi:10.1016/j.ejsobi.2009.10.003

[51] A. P. Oliveira, M. E. Pampulha and J. P. Bennett, "A Two-Year Field Study with Transgenic Bacillus thuringiensis Maize: Effects on Soil Microorganisms," Science of the Total Environment, Vol. 405, No. 1-3, 2008, pp. 351-357. doi:10.1016/j.scitotenv.2008.05.046

[52] A. L. Priestley and M. Brownbridge, "Field Trials to Evaluate Effects of Bt-Transgenic Silage Corn Expressing the CrylAb Insecticidal Toxin on Non-Target Soil Arthropods in Northern New England, USA," Transgenic Research, Vol. 18, No. 3, 2009, pp. 425-443. doi:10.1007/s11248-008-9234-Z

[53] S. Rauschen, J. Eckert, F. Schaarschmidt, I. Schuphan and A. Gathmann, "An Evaluation of Methods for Assessing the Impacts of Bt-Maize MON810 Cultivation and Pyrethroid Insecticide Use on Auchenorrhyncha (Planthoppers and Leafhoppers)," Agricultural and Forest Entomology, Vol. 10, No. 4, 2008, pp. 331-339. doi:10.1111/j.1461-9563.2008.00394.x
[54] R. Rose and G. P. Dively, "Effects of Insecticide-Treated and Lepidopteran-Active Bt Transgenic Sweet Corn on the Abundance and Diversity of Arthropods," Environmental Entomology, Vol. 36, No. 5, 2007, pp. 1254-1268. doi:10.1603/0046-225X(2007)36[1254:EOIALB]2.0.CO; $\underline{2}$

[55] C. C. M. Van De Wiel, R. M. W. Groeneveld, O. Dolstra, E. J. Kok, I. M. J. Scholtens, J. T. N. M. Thissen, M. J. M. Smulders and L. A. P. Lotz, "Pollen-Mediated Gene Flow in Maize Tested for Coexistence of GM and Non-GM Crops in the Netherlands: Effect of Isolation Distances between Fields," NJAS-Wageningen Journal of Life Sciences, Vol. 56, No. 4, 2009, pp. 405-423. doi:10.1016/S1573-5214(09)80007-9

[56] S. F. Yanni, J. K. Whalen and B. L. Ma, "Field-Grown Bt and Non-Bt Corn: Yield, Chemical Composition, and Decomposability," Agronomy Journal, Vol. 103, No. 2, 2011, pp. 486-493.

[57] A. R. Zeilinger, D. A. Andow, C. Zwahlen and G. Stotzky, "Earthworm Populations in a Northern U.S. Cornbelt Soil Are Not Affected by Long-Term Cultivation of Bt Maize Expressing Cry1Ab and Cry3Bb1 Proteins," Soil Biology and Biochemistry, Vol. 42, No. 8, 2010, pp. 1284-1292. doi:10.1016/j.soilbio.2010.04.004

[58] R. H. Gulden, P. H. Sikkema, A. S. Hamill, F. Tardif and C. J. Swanton, "Conventional vs. Glyphosate-Resistant Cropping Systems in Ontario: Weed Control, Diversity, and Yield," Weed Science, Vol. 57, No. 6, 2009, pp. 665-672. doi:10.1614/WS-09-023.1

[59] N. Z. Lupwayi, K. G. Hanson, K. N. Harker, G. W. Clayton, R. E. Blackshaw, J. T. O’Donovan, E. N. Johnson, Y. Gan, R. B. Irvine and M. A. Monreal, "Soil Microbial Biomass, Functional Diversity and Enzyme Activity in Glyphosate-Resistant Wheat-Canola Rotations under LowDisturbance Direct Seeding and Conventional Tillage," Soil Biology and Biochemistry, Vol. 39, No. 7, 2007, pp. 1418-1427. doi:10.1016/j.soilbio.2006.12.038

[60] E. Simpson, N. McRoberts and J. Sweet, "Out-Crossing between Genetically Modified Herbicide-Tolerant and Other Winter Oilseed Rape Cultivars," Plant Genetic Resources Characterization and Utilization, Vol. 4, No. 2, 2006, pp. 96-107. doi:10.1079/PGR2005103

[61] G. Bodulovic, "Is the European Attitude to GM Products Suffocating African Development?" Functional Plant Biology, Vol. 32, No. 12, 2005, pp. 1069-1075. doi:10.1071/FP05049

[62] I. K. Crombie and H. T. Davies, "What Is Meta-Analysis?" What is...? Series, 2009, pp. 1-8.

[63] S. E. Naranjo, "Impacts of Bt Crops on Non-Target Invertebrates and Insecticide Use Patterns," CAB Reviews: Perspectives in Agriculture, Veterinary Science, Nutrition and Natural Resources, Vol. 4, No. 011, 2009, pp. 1-11. doi:10.1079/PAVSNNR20094011

[64] Monsanto Australia Limited, "Bollgard II Cotton Technical Manual," 2003. 